\title{
ANTIPROLIFERATIVE PROTEIN FROM TRICHOSANTHES CUCUMERINA L. VAR ANGUINA (L.) HAINES
}

\author{
CHURIYAH* AND WAHONO SUMARYONO \\ Center for Medical and Pharmaceutical Technology \\ Agency for the Assessment and Application of Technology, \\ BPPT Building II, $15^{\text {th }}$ Floor, Jl. MH Thamrin no 8 Jakarta 10340, Indonesia
}

\begin{abstract}
Three proteins were isolated from plant parts of Trichosanthes cucumerina L. var anguina (L.) Haines, they were TF2 from fruit, TS3 from seed and TR3 from root with molecular masses (Mr) approximately $16-64 \mathrm{kDa}$ on SDS-PAGE characterization. The proteins were extracted with Phosphate Buffer Saline (PBS), then they were precipitated using $80 \%$ saturated ammonium sulphate continued with the dialysis using cellophane. The dialysate was fractionated through gel filtration chromatography. The highest yield of protein was $1.109 \%$ from the seed (TS3), then $0.356 \%$ from the root (TR3), while the lowest was $0.014 \%$ from the fruit (TF2). The Lethal Concentration $50\left(\mathrm{LC}_{50}\right)$ of proteins on brine shrimp lethality test was within range of $19 \mu \mathrm{g} / \mathrm{ml}-25 \mu \mathrm{g} / \mathrm{ml}$. The cytotoxicity test of the TR3 and TS3 proteins on cancer cell lines indicated that both of the proteins could inhibit proliferation of HeLa and $\mathrm{K}$ 562 cells with $\mathrm{IC}_{50}$ up to $45 \mu \mathrm{g} / \mathrm{ml}$. It is recommended to conduct further researches on Trichosanthes plant as a herbal medicine to treat cancer.
\end{abstract}

Keywords: Trichosanthes cucumerina L. var anguina (L.), plant parts, protein, yield, toxicity, cytotoxicity, molecular mass.

\section{INTRODUCTION}

Trichosanthes cucumerina L. var anguina (L.) Haines is both a tropical and subtropical plant, its popular name is snake gourd, and in Indonesia it is called 'paria ular'. This plant is one of the species of the genus Trichosanthes that is widely cultivated in Indonesia. The plant prefers sandy, loamy and clay soils to grow and requires welldrained soil. It can grow whether in acid, neutral or base soils. It cannot grow under the shade and requires moist soil. The flowers are monoecious, individual flowers are either male or female, with both sexes on the same plant and pollinated by insects (Gildemayer et al. 1994).

*Corresponding author: churiyah_zafrollah@yahoo.com 
The fruit is used as vegetable and as medicine, where several bioactive proteins were found from this genus of Trichosanthes. Lee-Huang et al. (1991) isolated and purified the anti-human immuno-deficiency virus (anti-HIV) protein capable of inhibiting HIV-1 infection and replication. This protein was TAP 29 (Trichosanthes antiHIV protein, $29 \mathrm{kDa}$ ) from Trichosanthes kirilowii. Toyokawa et al. (1991) discovered an abortifacient protein named karasurin, from fresh root tubers of Trichosanthes kirilowii Maximowicz var.japonicum Kitamura.

Chow et al. (1999) isolated and purified trichoanguin a type of I ribosomeinactivating protein (RIP) from the seeds of Trichosanthes anguina plant. This protein contains two cysteine residues which were found to be located on the protein surface that are directly amenable for conjugation with antibodies to form immunoconjugates. It is therefore conceivable that trichoanguin might be a good type of I RIP so far examined for the preparation of immunotoxin, having a great potential as an effective chemotherapeutic agent for the treatment of cancer.

Chi et al. (2001) isolated a genomic clone encoding trichobakin (TBK), a type I ribosome-inactivating protein from the Trichosanthes sp. plant. It was found that the protein inhibited luciferase mRNA translation in the rabbit reticulocyte cell-free system. The RIPs trichosanthin from Trichosanthes sp is a potential anti-mitogenic agent that suppressed the mitogenic response of murin splenocytes to concanavaline A. The protein also acted as anti-phage protein which has capability to inhibit replication of phage M13 in the bacterium Escherichia coli (Wang \& Ng 2001). Fei et al. (2004) isolated T33, a putative type 2 ribosome inactivating protein (RIP), from dried roots of Trichosanthes kirilowii Maximovicz.

The research was conducted to isolate and characterize the cytotoxic protein from plant parts of Trichosanthes cucumerina L. var anguina (L.), including fruits, seeds and roots, which have toxic effect on brine shrimp nauplii and cytotoxic activity on cancer cell lines. The protein toxicity was analyzed through brine shrimp lethality test (BSLT) and followed by a cytotoxicity test using cancer cell lines.

\section{MATERIALS AND METHODS}

\section{Plant propagation}

Seeds were sown in polybags inside the greenhouse. After germination and they were large enough, the seedlings were planted in individual pots provided with compost and transferred to the experimental field of IPB Baranangsiang. The plant growth was observed, including time of germination, time of flowering and fruit harvesting.

\section{Extraction of protein}

The protein extraction was performed in accordance with the procedure of Di Toppi et al. (1996) with some modifications. Fruit, seeds and roots were washed under tap wáter and grounded in cold phosphate buffered saline (PBS) consisting of 0.14 $\mathrm{mM} \mathrm{NaCl}$ in $5 \mathrm{mM}$ Na phosphate buffer, $\mathrm{pH} 7$ homogenized on the same buffer with 
the ratio of 1:4 (w/v). Each homogenate was stirred overnight at $4^{\circ} \mathrm{C}$, filtered and the supernatant was centrifuged at $10000 \mathrm{~g}$ for 25 minutes. The protein was precipitated by $80 \%$ saturated ammonium sulfate, then the extracted protein was dialysed against $5 \mathrm{mM}$ Na phosphate buffer, $\mathrm{pH} 7$ using cellophane. After removal of insoluble material by centrifugation, the dialysates were lyophilized.

\section{Gelflitration chromatography}

Protein fractionation using gel filtration chromatography followed the procedure of Di Toppi et al. (1996). Crude proteins were diluted on $5 \mathrm{mM}$ Na phosphate buffer, pH7 and subjected to gel filtration on Sephadex G-75, equilibrated and eluted in the same buffer. The excluded proteins were detected from their absorbance at $280 \mathrm{~nm}$ wavelength, then the same fractions were pooled and lyophilized.

\section{Polyacrylamide gel electrophoresis}

Proteins were incubated within $1 \%$ sodium dodecyl sulfate (SDS) and 1\% 2mercaptoethanol at $50^{\circ} \mathrm{C}$ for 2 hours. Electrophoresis of the protein was done on a polyacrylamide slab consisting of $13 \%$ separating gel and $5 \%$ stacking gel in the presence of $0.1 \%$ SDS. The gels were stained with Coomassie brilliant blue (R-250) and the protein molecular mass $(\mathrm{Mr})$ was obtained after the retention time was calculated and calibrated with the LMW (low molecular weight) protein standards. The standards were lysozime $(14 \mathrm{kDa})$, tyrosine $(20 \mathrm{kDa})$, carbonic anhydrase $(30 \mathrm{kDa})$, ovalbumin $(45 \mathrm{kDa})$ and albumin $(66 \mathrm{kDa})$.

\section{Brine shrimp lethality test (BSLT)}

A hatching brine shrimps system was set up with temperatures between $28^{\circ}$ and $30^{\circ} \mathrm{C}, 30-35$ ppm salinity, $\mathrm{pH}$ range of 8-9 and strong aeration under a continuous light regime. After these conditions are fulfilled, about one teaspoon of brine shrimp eggs was added into the system. After approximately 48 hours of hatching, the phototropic naupliis were collected with a pipette from the lighted side and concentrated in a small beaker applied for testing. Different concentrations $(0,10,100 \& 1000 \mu \mathrm{g} / \mathrm{ml})$ of the protein samples were prepared. These protein samples were placed in separated test tubes. Twenty brine shrimps were transferred to each test tube using micro pipettes. After 24 hours, the test tubes containing different concentrations of protein samples were observed and the number of survived nauplii in each test tube was calculated. The lethality percentage of brine shrimp nauplii was calculated at each concentration representing each sample. The values of $\mathrm{LC}_{50}$ were calculated using a Finny computer program.

\section{Cytotoxicity on cancer cell line}

HeLa (human servic carcinoma) cells was maintained as monolayer cultures in RPMI 1640 medium, supplemented with $1 \%$ antibiotics $(50 \mathrm{IU} / \mathrm{ml}$ penicillin and 50 $\mu \mathrm{g} / \mathrm{ml}$ streptomycin) and $10 \%$ fetal bovine serum in a humidified incubator containing $5 \% \mathrm{CO}_{2}$ at $37{ }^{\circ} \mathrm{C}$. Subcultures were obtained by trypsin treatment of confluent cultures. The K-562 (human erythro leukemia) cell line was grown in 
suspension in the same medium. The cells were plated in $100 \mu \mathrm{l}$ of medium in 96 microwell plates at a density of $10^{4}$ cells/well for HeLa and $5 \times 10^{3}$ cells/well for K-562, and the plates were placed in a $37^{\circ} \mathrm{C}, 5 \% \mathrm{CO}_{2}$ incubator. One day later the cell culture medium was added with $100 \mu \mathrm{l} /$ well medium containing the indicated concentrations $(0,10,20,30,40$ and $50 \mu \mathrm{g} / \mathrm{ml})$ of protein in triplicate. After 72 hours of treatment, the cells were harvested. We compared the different concentrations of each protein which inhibited the growth of both cell lines, using the MT'T [3-(4,5-dimethyi-2-thiazolyl)-2, 5-diphenyl-2H-tetrazolium bromide] dye uptake method. Each cell was added with 10 $\mu \mathrm{l}$ of $0.5 \mathrm{mg} / \mathrm{ml}$ of $\mathrm{MTT}^{\circ} \mathrm{T}$ and maintained at $37^{\circ} \mathrm{C}$ in $5 \% \mathrm{CO} 2$ incubator for 4 hours to allow MT'T to be converted to formazon crystals by reacting it with metabolically active cells. The reaction was stopped by adding acidic isopropanol $(34 \mu \mathrm{l} \mathrm{HCl}$ in $10 \mathrm{ml}$ isopropanol) and the cell viability was measured at $570 \mathrm{~nm}$ using a plate reader (Wang et al.2000).

\section{RESULTS AND DISCUSSIONS}

The growth of plant in the experimental field of IPB Baranangsiang was good enough and the flowering stage was completed within 5-6 weeks after planting The 40-60 cm long immature fruits were picked about 8 weeks after planting, while the mature fruits were harvested about 13-16 weeks after planting. The plants grew well on the experimental field of IPB Baranangsiang as in other fields, therefore the samples could represent other Trichosanthes cucumerina plant in general.

Materials used as source of protein were immature fruits, seed from the mature fruits and also the roots from harvested plant. The result of protein extraction was described by protein yield, that is the ratio between the proteins resulted from the extraction process and the extracted materials. The protein yield was considerably higher in the seed than in the root, while the lowest was in the fruit (Table 1). The lowest yield was $0.054 \%$ resulted from fruit protein due to high water content up to $96 \%$ from the edible parts (Gildemayer et al. 1994). Therefore, fruit is not recommended as the source of protein, but still can be used for other applications, for example to decrease cholesterol level and body weight. Previous research reported that the consumption of aqueous fruit extract of Trichosanthes dioica Roxb (L.) by normal and streptozotocin diabetic rats could decrease cholesterol level and body weight (Sharmila Banu et al. 2007).

Table 1. Protein yields and their fractions from fruit, seed and root protein of T. Cucumerina L. var anguina (L.) Haines and their toxicities on BSLT.

\begin{tabular}{cccccc}
\hline \multicolumn{3}{c}{ Before fractionation } & \multicolumn{3}{c}{ After fractionation } \\
\hline Plant & Yield & $\mathrm{LC}_{50}$ & Protein & Yield & $\mathrm{LC}_{50}$ \\
Part & $(\%)$ & $(\mu \mathrm{g} / \mathrm{ml})$ & Fraction & $(\%)$ & $(\mu \mathrm{g} / \mathrm{ml})$ \\
\hline Fruit & 0.054 & 27 & TF2 & 0.014 & 21 \\
Seed & 3.62 & 39 & TS3 & 1.109 & 19 \\
Root & 1.68 & 53 & TR3 & 0.356 & 25 \\
\hline
\end{tabular}


Whereas the highest yield was resulted from the seed protein followed by the root protein approximately $3.62 \%$ and $1.68 \%$, respectively, from fresh weight extracted material. Therefore, both seed and root proteins should be further investigated. There were similarities between the result of this experiment with previous researches which reported that seed and root of Trichosanthes were sources of bioactive proteins. For example, Trichoanguin - a type I ribosome-inactivating protein (RIP) was isolated and purified from the seeds of Trichosanthes anguina, (Cho et al. 1999). Karasurin - an abortifacient protein was isolated from fresh root tuber of Trichosanthes kirilowi Maximowicz var. japonicum Kitamura (Toyokawa et al. 1991). T33 - a putative ribosome inactivating protein (RIP) was isolated from dried roots of Trichosanthes kirilowii Maximovicz (Fei et al. 2004).

Protein fractionation using gel filtration chromatography could separate proteins according to their size or molecular weight. Using Sephadex G-75 as a matrix resulted in porosities that could be passed by proteins with molecular mass about 3-80 kDa. Smaller molecules diffuse further into the pores of the beads and move through the bead more slowly, while larger molecules enter less or not at all and thus move through the bead more quickly (Janson \& Ryden 1998). Crude proteins were diluted and subjected to gel filtration on Sephadex G-75, the excluded proteins were detected on the basis of their absorbance at $280 \mathrm{~nm}$ wavelength. The chromatography elution profile (Fig. 1) showed the fractionation of fruit protein which could be separated into four peaks, while the root and seed protein could only be separated into three peaks. All protein fractions were analyzed for their toxicities through BSLT and the best fraction was elected according to the high yield and toxicity (data not shown). The three selected protein fractions were TF2 from fruit protein, TS3 from seed protein and TR3 from root protein.

SDS-PAGE pattern of each protein fraction was visualized by Coomassie brilliant blue staining, as shown on Figure 2. All of the protein fractions showed more than one sub unit molecular mass. The molecular masses of fruit protein fraction TF2 were $17 \mathrm{kDa}$ and $28 \mathrm{kDa}$, root protein fraction TR3 were $19 \mathrm{kDa}$ and $29 \mathrm{kDa}$, and seed protein fraction TS3 were $16 \mathrm{kDa}, 22 \mathrm{kDa}$ and $64 \mathrm{kDa}$.

The protein toxicities on BSLT is visualized by $\mathrm{LC}_{50}$ which showed the concentration of protein killing 50\% of the tested animal. LC $_{50}$ is inversely proportional to the toxicity of a compound which means that the lower the $\mathrm{LC}_{50}$, the higher becomes the toxicity. As shown on Table 1, each of the tested protein was toxic within 24 hours at different concentrations. The rate of lethality or mortality was increased by increasing each sample concentration. The result indicates that before fractionation, the fruit protein showed the most toxic protein against the brine shrimp nauplii, followed by the seed and the root protein. After fractionation, the seed protein fraction became more active than the fruit protein fraction, and the root protein was still considered as the less active. In the control all of the naupliis were alive after 24 hours. So it could be concluded that the toxicity found in the experiment may represent the toxic property of the protein. 

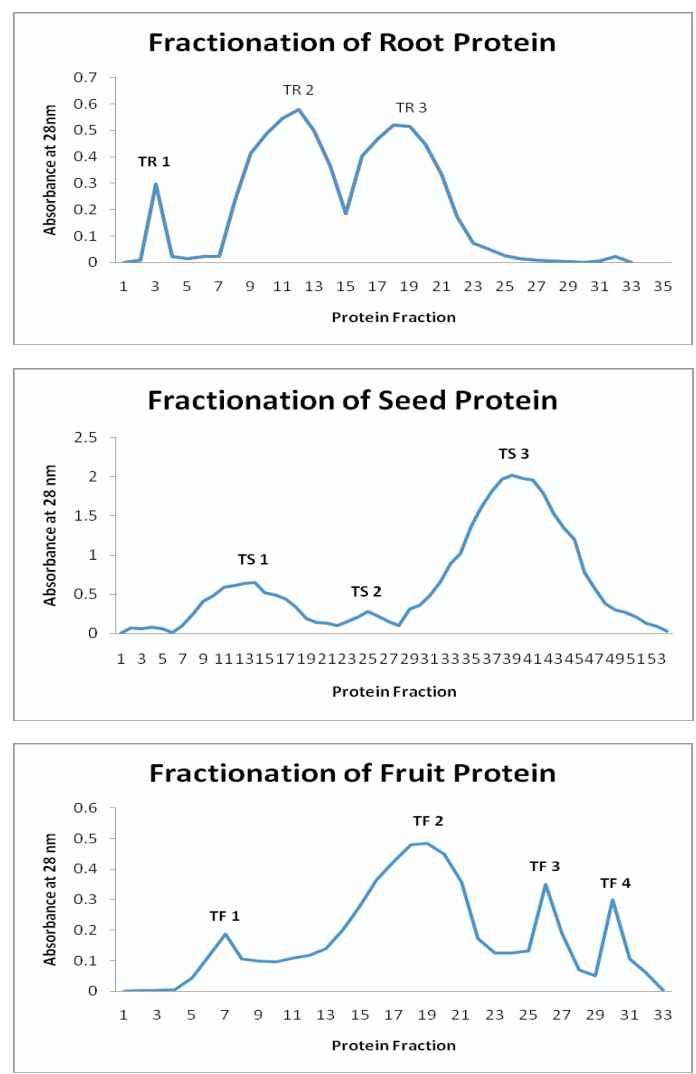

Figure 1. Chromatography elution profile of the root, fruit and seed proteins of Trichosanthes cucumerina L. var anguina (L.) Haines, on fractionation using gel filtration chromatography.

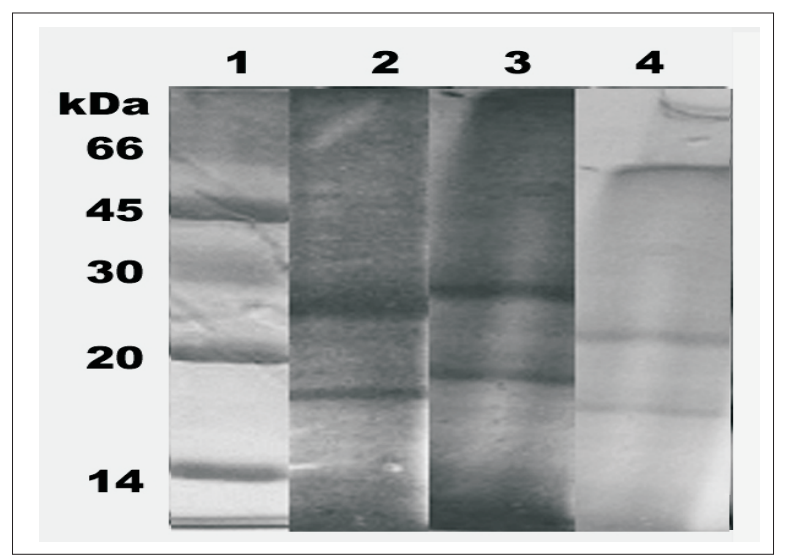

Figure 2. SDS-PAGE of protein fractions from plant parts of T.cucumerina L. var anguina (L.) Haines: 1. Standard protein LMW, 2. Fruit protein TF2, 3. Root protein TR3, 4. Seed protein TS3. 
According to their protein yield and their toxicities on BSLT root protein fraction TR3 and seed protein fraction TS3 were selected for further experiment. The cytotoxic activities of both selected protein on cancer cell lines were analyzed. The correlation between concentration of both proteins and their cytotoxic effect on HeLa and K-562 cells were investigated by MT'T assay. Cells were treated with proteins at concentrations ranging from 10 to $50 \mu \mathrm{g} / \mathrm{ml}$ for 72 hours, then the percentage of cell viability was calculated.

Result of the last experiment indicated that both proteins were effective on inhibiting the growth of both two tested cell lines. The root protein inhibited the growth of the HeLa cell in the range of 3.08-26.39\% and the growth of the K-562 cell was inhibited in the range of $9.3-42.83 \%$. While the seed proteins inhibited the growth of HeLa cell in the range of 9.7-37.6\% and the growth of K-562 cell in the range of $11.15-57.81 \%$. The inhibitory effect of the protein extract was dosedependent (Fig. 3). The protein addition showed different proliferative inhibiting rates at different concentrations and increased in line with the increasing concentration of the protein.

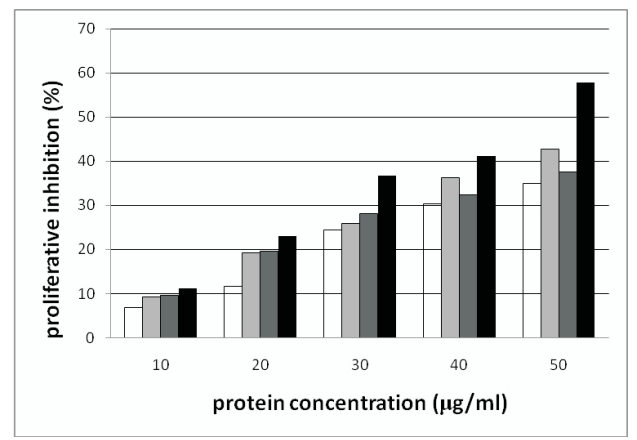

Figure 3. Comparison of the antiprolative activity of the root and seed protein fractions on HeLa and K-562 cell lines using MT'T method.

$\square=$ proliferative inhibition activity of the root protein fraction on HeLa cell

$\square=$ proliferative inhibition activity of the root protein fraction on K-562 cell

$\square=$ proliferative inhibition activity of the seed protein fraction on HeLa cell

= proliferative inhibition activity of the seed protein fraction on K-562 cell

Both proteins were actively inhibiting the proliferation of Hela and K-562 cell lines, although the mechanism of action was not clear yet. Previous researches reported the activity of many active compounds found in another genus of Trichosanthes on cancer treatment. According to Hyuncheol et al. (2002) cucurbitacins from Trichosanthes kirilowii act as the inhibitory component on tyrosinase activity and melanin synthesis of B16/F10 melanoma cells.

Recently, Takasakhi et al. (2009) reported that active compound cucurbitacin D isolated from Trichosanthes kirilowii induces apoptosis through caspase-3 and phosphorylation of JNK in hepatocellular carcinoma cells. Cucurbitacin B and D are in the process to be patented as recent study provides a method of isolating and purifying the active ingredients on lab-and industrial-scale. 


\section{CONCLUSIONS}

Two antiproliferative proteins were isolated from Trichosanthes cucumerina L. var anguina (L.) Haines plant, they were TR3 from root protein fraction and TS3 from seed protein fraction, with molecular masses in the range of $16-64 \mathrm{kDa}$ on SDS PAGE characterization. Both of them actively inhibit proliferation of HeLa and K-562 cancer cell lines.

It is recommended to conduct further researches to determine the proliferation inhibiting mechanism of the protein. Moreover, this research contributes to the findings of Trichosanthes plant, not only as vegetables, but also to be developed as a herbal medicine to treat cancer.

\section{REFERENCES}

Chi P.V., Truong H.O., Ha N.T., Won-li.C. and L.T. Binh. 2001. Characterization of trichobakin, a type I ribosome-inactivating protein from Trichosanthes sp. Biotechnology and Applied Biochemistry, 34(2): $85-92$.

Chow L.P., Chou M.H., Ho C.Y., Chuag C.C., Pan F.M., Wu S.H. and J.Y. Lin. 1999. Purification, characterization and molecular cloning of trichoanguin, a novel type I ribosome-inactivating protein from the seeds of Trichosanthes anguina, Biochemical Journal, 338:211219.

Di Toppi L.S., Gorini P., G. Properzi G., Barbieri L. and L. Spano. 1996. Production of ribosome-inactivating protein from hairy root cultures of Luffa cylindrica (L.) Roem. Plant Cell Reports, 15: 910-913.

Fei X., Marco H., Ma X., Teng L., Li Q. and S. Joachim. 2004. Isolation of a putative ribosome inactivating protein from dried roots of Trichosanthes kirilowii used in Traditional Chinese medicine. Planta medica, 70(4):364-365.

Gildemacher B.H., Jansen G.J. and K. Chayamarit. 1994. Trichosanthes L. Siemonsma J.S. and Kasem K. (eds.). Plant Resources of South-East Asia, 8:271-274.

Hyuncheol O.H., Yeun-Ja M.U.N, Sook-Jung I.M., Lee S.Y., Song H.J., Ho-Sub L. and W. Won-Hong. 2002. Cucurbitacins from Trichosanthes kirilowii as the inhibitory components on tyrosinase activity and melanin synthesis of B16/F10 melanoma cells. Planta medica, 68 (9): 832-833.

Jason J.C. and L. Ryden. 1998. Protein Purification, Principles, High Resolution, Methods, and Applications. New York: John Wiley \& Sons.

Lee-Huang S., Huang P.L., Kung H.F., Li B.Q., Huang P., Huang H.I. and H.C. Chen. 1991. TAP 29: an antihuman immunodeficiency virus protein from Trichosanthes kirilowii that is nontoxic to intact cells. Proceedings National Academy of Science, 88: 6570-6574.

Meyer B.N., Ferrigni N.R. And J.E. Putnam. 1982. Brine shrimp: a convenient general bioassay for active plant constituents. Planta medica, 45: 31-34.

Sharmila B.G., Kumar G. and M. Rajasekara Pandian. 2007. Cholesterol lowering activity of the aqueous fruit extract of Trichosanthes dioica Roxb (L.) in Normal and Streptozotocin Diabetic Rats. Experimental Research, 1(6): 561-569.

Takahashi N., Yoshida Y., Sugiura T., Matsuno K., Fujino A. and U. Yamashita. 2009. Cucurbitacin D isolated from Trichosanthes kirilowii induces apoptosis in human hepatocellular carcinoma cells in vitro. International Immunopharmacology, 9 (4): 508-513.

Toyokawa S., Takeda T. and Y.Ogihara. 1991. Isolation and characterization of a new abortifacient protein, karasurin, from root tubers of Trichosanthes kirilowii Max. var. japonicum Kitam. Chemical \& Pharmaceutical Bulletin (Tokyo), 39: 716-719. 


\section{BIOTROPIA Vol. 17 No. 1, 2010}

Wang H., Gao J. and T.B. Ng. 2000. A new lectin with highly potent antihepatoma and antisarcoma activities from the oyster mushroom Pleurotus ostreatus. Biochemical and Biophysical Research Communications, 275:810-816.

Wang H.X. and T.B. Ng. 2001. Studies on the anti-mitogenic, anti-phage and hypotensive effects of several ribosome inactivating proteins. Comparative Biochemestry and Physioliology Part C: Toxicology \& Pharmacology, 128(3):359-366. 